\title{
Interactive effects of inducible defense and resource availability on phlorotannins in the North Atlantic brown alga Fucus vesiculosus
}

\author{
P. Peckol ${ }^{1, *}$, J. M. Krane ${ }^{1}$, J. L. Yates ${ }^{2}$ \\ ${ }^{1}$ Department of Biological Sciences, Smith College, Northampton, Massachusetts 01063, USA \\ ${ }^{2}$ School of Education, Educational Studies, University of Michigan, Ann Arbor, Michigan 48109, USA
}

\begin{abstract}
Research seeking to explain the ecological role of polyphenolics (phlorotannins) in plants and brown algae has largely focused on 2 alternative concepts, the carbon/nutrient ( $\mathrm{C} / \mathrm{N}$ ) balance and the inducible defense models. We tested the hierarchy of effects of both models on phlorotannin production in the brown alga Fucus vesiculosus (Fucales) by simultaneously manipulating the $N$ environment and simulating herbivory for 2 oceanic (high and low intertidal) and estuarine populations. We measured phlorotannin levels in algae under control, grazed, N-enriched, and grazed + N-enriched treatments with time $(0$ to $14 \mathrm{~d})$ throughout the year to determine onset and duration of the response. We found greater support for the inducible defense model; generally, both grazed and grazed $+\mathrm{N}$ enriched fronds had significantly higher phlorotannin concentrations than control thalli. When we found an inducible response, it was rapid (within $3 \mathrm{~d}$ ) and relatively long term ( $>2 \mathrm{wk}$ ). However, the induced response was minimal for both oceanic populations during March, perhaps due to fixed-C limitation, and was absent for the estuarine and high intertidal populations during June, the period of peak phlorotannins at both sites. Although $N$ enrichment resulted in depressed concentrations of phlorotannins only for the estuarine population, we did measure a significant negative correlation between tissue $\mathrm{N}$ and phenolics for the oceanic population, as predicted by the $\mathrm{C} / \mathrm{N}$ balance model. Thus, while the inducible defense response takes preeminence over resource availability effects $(\mathrm{C} / \mathrm{N}$ balance hypothesis), this study revealed that phlorotannin production is likely controlled by a complex interaction of environmental, developmental and defense-related factors, emphasizing the applicability of both models in marine systems.
\end{abstract}

KEY WORDS: Brown algae Fucus Inducible defense - Marine herbivory Phlorotannins - Resource availability

\section{INTRODUCTION}

Recently, much research has focused on determining the ecological role of secondary metabolites in terrestrial and marine primary producers (see Hay \& Steinberg 1992, Herms \& Mattson 1992). Both plants and brown algae produce a class of carbon (C)-based secondary metabolites, polyphenolics (also called phlorotannins in brown algae; Ragan \& Glombitza 1986, Hay \& Fenical 1988), originating from the shikimic acid pathway (Lobban et al. 1985), that seem to have multi-

•E-mail: ppeckol@science.smith.edu ple functions. Although polyphenolics play an important role in plant (and algal)-herbivore interactions due to their demonstrated effectiveness as herbivore deterrents (Levin 1971, Swain 1979, Karban \& Myers 1989 , Steinberg \& Paul 1990, Hay \& Steinberg 1992, Yates \& Peckol 1993, but see Steinberg \& van Altena 1992), these compounds also serve in other capacities, such as chelators of heavy metals (Ragan et al. 1979) and storage of surplus fixed carbon, particularly under conditions of nutrient deficiency (Mattson 1980, Bryant et al. 1983, Gershenzon 1984j. Understanding the ecological trade-offs in allocation of $\mathrm{C}$-based resources between primary and secondary metabolic pathways is critical to predicting the success of a producer in its environ- 
ment. However, determining what triggers production of these secondary metabolites has been confounded by conflicting effects of environmental and defenserelated factors (Mattson 1980, Karban \& Myers 1989, Hay \& Steinberg 1992, Herms \& Mattson 1992, Yates \& Peckol 1993).

The prevailing evidence that natural and simulated herbivory triggers production of secondary metabolites in terrestrial (Baldwin \& Schultz 1983, Baldwin 1988a, b, Karban \& Myers 1989, but see Bryant et al. 1983) and marine (Van Alstyne 1988, Yates \& Peckol 1993, but see Steinberg 1994) systems suggests that defense mechanisms in some species of plants and brown algae are inducible. As predicted by the inducible defense hypothesis (Karban \& Myers 1989), grazing may induce a response within hours (Carroll \& Hoffman 1980, Baldwin \& Schultz 1983) that may be maintained for weeks (Haukioja \& Neuvonen 1985, Van Alstyne 1988, Yates \& Peckol 1993). The timing of onset and the duration of the response (short or long term), as well as sensitivity to subsequent attack, are all qualities of the induced response that vary among species (Karban \& Myers 1989, Harvell 1990), due, in some cases, to trade-offs between primary and secondary metabolism (Herms \& Mattson 1992).

The carbon/nutrient $(\mathrm{C} / \mathrm{N})$ balance hypothesis offers an alternative to the induced defense model. Rather than linking polyphenolic production to grazing pressure, the $\mathrm{C} / \mathrm{N}$ balance hypothesis argues that secondary metabolite production is regulated by the relative amounts of fixed $\mathrm{C}$ and $\mathrm{N}$ (Bryant et al. 1983, Fajer et al. 1992). Under conditions of high irradiance and low $\mathrm{N}$ availability (high $\mathrm{C} / \mathrm{N}$ ratio), for example, plants (Bryant et al. 1983) and brown algae (Ilvessalo \& Tuomi 1989, Yates \& Peckol 1993) will accumulate C-based carbohydrate reserves, because moderate $\mathrm{N}$ deficiency limits growth more than photosynthesis (Fajer et al. 1992, Herms \& Mattson 1992). Under conditions of low light, which may result in a low $\mathrm{C} / \mathrm{N}$ ratio if $\mathrm{N}$ is in sufficient supply, excess carbohydrates may not be available for allocation to secondary metabolic pathways. Therefore, according to the $\mathrm{C} / \mathrm{N}$ hypothesis, plants or algae grown in low light or high $\mathrm{N}$ environments will likely have lower concentrations of polyphenolics than those grown in high light (or low $\mathrm{N}$ ) environments.

Although the induced defense and $\mathrm{C} / \mathrm{N}$ balance models offer alternative explanations for what triggers production of polyphenolics in plants and brown algae, they may not be mutually exclusive. Yates \& Peckol (1993) examined the effects of simulated herbivory and $N$ enhancement on phlorotannin production of the intertidal brown alga Fucus vesiculosus to ascertain the extent to which the alga was influenced under each condition. As predicted by the $\mathrm{C} / \mathrm{N}$ balance model, under high $\mathrm{N}$ conditions, phlorotannin produc- tion was sometimes depressed compared to production under the low $\mathrm{N}$ conditions. Because the induced defense model was also supported by their data, neither model was confirmed as the more significant predictor of phlorotannin production by brown algae. Here, we test both the induced defense and the $\mathrm{C} / \mathrm{N}$ balance models simultaneously to evaluate the hierarchy of influence on the production of phlorotannins by estuarine and oceanic populations of Fucus vesiculosus L. Our experiments were designed to determine the timing of onset and duration of the inducible response, singly and in association with a manipulated $\mathrm{N}$ environment. We also considered temporal and spatial effects on levels of phlorotannins.

\section{MATERIALS AND METHODS}

Study sites. Our oceanic site, Ft. Wetherill State Park, Jamestown, Rhode Island, USA (see Peckol et al. 1990 for exact location), is a semi-sheltered rock outcropping with an annual water temperature range of 0 to $20^{\circ} \mathrm{C}$ and relatively stable salinity ( 34 to $35 \mathrm{ppt}$ ). Fucus vesiculosus was the dominant intertidal algal species, and the common periwinkle Littorina littorea, an important herbivore, occurred in densities sometimes exceeding $100 \mathrm{~m}^{-2}$ at this site (Peckol unpubl. data).

Our estuarine site, Sage Lot Pond, was located in Waquoit Bay, an NOAA National Estuarine Research Reserve in Falmouth, Massachusetts, USA (see Peckol et al. 1994 for exact location). The annual range in water temperature was 0 to $28^{\circ} \mathrm{C}$, and salinity varied from 27 to 33 ppt. Fucus vesiculosus dominated the intertidal peat substrata of a Spartina alterniflora saltmarsh. Littorina littorea occurred in abundances an order of magnitude lower than densities measured at the oceanic site (Peckol unpubl. data).

Algal tissue constituents. Healthy, ungrazed vegetative Fucus vesiculosus fronds were collected monthly from March to November from the oceanic site, Ft. Wetherill, to monitor temporal variations in phlorotannins. Temporal and spatial variations in tissue constituents of $F$. vesiculosus from the estuarine site have already been documented (Yates \& Peckol 1993). We collected samples in the upper (top $15 \mathrm{~cm}$ of $F$, vesiculosus zone) and lower (mean low water, MLW) regions at this site to investigate spatial patterns in phlorotannin levels. Samples were immediately analyzed for total phlorotannin content, tissue nitrogen $(\mathrm{N})$ and light-harvesting pigment levels.

Total phlorotannin concentrations ( $\mathrm{mg} \mathrm{g}^{-1}$ dry wt) were determined using a variation (Andersen \& Sowers 1968, Andersen \& Todd 1968, Ragan \& Craigie 1978, Yates \& Peckol 1993) of the Folin-Denis method 
(Swain \& Hillis 1959). Samples ( $n=10$ to 14 ) were rinsed in fresh water, preweighed (fresh weight) and held in chilled $70 \% \mathrm{MeOH}$. If immediate extraction was not possible, samples were stored in darkness $\left(-80^{\circ} \mathrm{C}\right)$. The specimens $(0.25$ to $0.40 \mathrm{~g}$ fresh wt $)$ were ground in $10 \mathrm{ml}$ of $70 \% \mathrm{MeOH}$ with a Polytron tissue homogenizer, flushed exhaustively with nitrogen gas to remove oxygen, and shaken in cold darkness overnight (Ragan \& Craigie 1978). The next day, aliquots of samples were diluted (4:1) with $10 \% \mathrm{MeOH}$ (pH 3.5) and divided into 2 portions. To one set of samples, $0.75 \mathrm{~g}$ of insoluble polyvinylpolypyrrolidone (PVPP) was added (+PVPP), and repeatedly shaken for 30 min to keep PVPP in contact with the phlorotannins Andersen \& Sowers (1968) reported maximum binding within a 10 min shaking period. The remaining set of samples received no PVPP (-PVPP). Because the FolinCiocalteu reagent reacts with other constituents in addition to phlorotannins, such as amino acids and proteins (Andersen \& Todd 1968), treatment with PVPP permitted a more accurate measure of polyphenolic concentrations (Yates \& Peckol 1993). Although Van Alstyne (1995) reported $<100 \%$ efficiency of PVPP and phlorotannin binding, her conditions $(80 \% \mathrm{MeOH}$, $\mathrm{pH} \approx 1.0$ ) varied from ours. Andersen \& Sowers (1968) documented optimal binding of PVPP and polyphenolics at low concentrations of $\mathrm{MeOH}$ and $\mathrm{pH}$ 3.5. Phlorotannin levels were determined as the absorbance difference between the +PVPP and -PVPP samples, and concentrations were calculated from a standard curve of phloroglucinol using regression analysis. Phlorotannins were expressed in per $g$ dry wt after determining the fresh-to-dry weight relationship with linear regression (Yates unpubl. data).

Carbon and nitrogen contents in tissues were determined on oven-dried $\left(80^{\circ} \mathrm{C}\right)$, homogenized samples of Fucus vesiculosus. Samples $(\mathrm{n}=3)$ were analyzed using a Perkin-Elmer $2400 \mathrm{CHN}$ elemental analyzer.

We determined concentrations ( $\mathrm{mg} \mathrm{g}^{-1}$ dry $w \mathrm{t}$ ) of the light-harvesting pigments (chl $a, c$, and fucoxanthin) for the high and low intertidal populations ( $\mathrm{n}=10$, each population) of Fucus vesiculosus at Ft. Wetherill, the oceanic site. We performed a double extraction of ground tissues (fresh wt), first for $15 \mathrm{~min}$ in dimethyl sulfoxide (DMSO), then in $\mathrm{MeOH}$ (Duncan \& Harrison 1982). Deionized water was added to the DMSO fraction (DMSO: $\mathrm{H}_{2} \mathrm{O}=4: 1$ ) and absorbances were read at $480,582,631$, and $665 \mathrm{~nm}$. Deionized water and acetone were added to the $\mathrm{MeOH}$ fraction (acetone: $\mathrm{MeOH}: \mathrm{H}_{2} \mathrm{O}=3: 1: 1$, and absorbances were read at $470,581,631$, and $664 \mathrm{~nm}$. Concentrations were calculated using the equations of Seely et al. (1972).

Grazer simulation. To test the inducible defense response of Fucus vesiculosus over a time period of 0 to $14 \mathrm{~d}$, we simulated grazing activity by the herbivore
Littorina littorea in the field during late winter (March), summer (June and August), and autumn (October). Using a paper hole punch to mimic the size and shape of the grazing wound inflicted by L. littorea (Yates \& Peckol 1993), we excised tissue along the periphery of the apical region of whole, attached vegetative thalli. Small cable ties attached to the stipes identified this treatment. Control (ungrazed) clumps were interspersed with the grazed treatment. Depending on the experiment and location, we collected samples from the grazed and control treatments after 3,7 , and $14 \mathrm{~d}$ for total phlorotannin determination.

Nutrient enrichment. To determine the relationship between $\mathrm{N}$ availability and phlorotannin production, we enriched oceanic and estuarine populations of Fucus vesiculosus during the same times we ran grazing experiments. Small muslin bags containing $10 \mathrm{~g}$ each of slow-release ammonium fertilizer (Osmocote, Sierra Chemical Company) were placed near the thalli of $F$. vesiculosus at both sites; apical regions of algal fronds were within $10 \mathrm{~cm}$ of the fertilizer. Water samples taken near enriched treatments contained ammonium concentrations $>20$-fold higher than control areas (estuarine site: Yates \& Peckol 1993; oceanic site: Peckol, Levings \& Garrity unpubl. data). Elemental analysis indicated that this enrichment regime consistently resulted in a significant elevation of tissue $\mathrm{N}$ above control fronds in estuarine Fucus vesiculosus (Yates \& Peckol 1993); N-enriched fronds from the oceanic site had tissue $\mathrm{N}$ values nearly double those of control fronds for both high (control: $\sim 1.2 \% \mathrm{~N}$; enriched: $\sim 2.3 \% \mathrm{~N}$ ) and low (control: $\sim 1.3 \% \mathrm{~N}$; enriched: $-2.1 \% \mathrm{~N}$ ) intertidal populations. Control fronds were separated by several meters to avoid any fertilization effect. We collected samples 7 and $14 \mathrm{~d}$ after enrichment for determination of phlorotannin concentrations.

Interactive effects of grazing and enrichment. To determine the interactive effects of simulated grazing and $\mathrm{N}$ enrichment on phlorotannin production, we experimentally clipped and enriched estuarine and oceanic populations of Fucus vesiculosus in the manner described above. We collected samples 7 (Ft. Wetherill) and 14 (both sites) days after treatment and handled them as described above.

Statistical analysis. We used 2-way analysis of variance (ANOVA) to determine temporal and site-related (tidal height) variations in phlorotannins. $t$-tests were used to compare pigment and tissue $\mathrm{N}$ concentrations between fronds collected at 2 tidal heights at the oceanic site. One-way ANOVA or t-tests were used in the analysis of phlorotannins following experimental treatment. Tukey's test was used to make multiple comparisons among treatment means from significant ANOVA tests (Day \& Quinn 1989). Homogeneity of variance was determined using the $F_{\max }$ test (Sokal \& Rohlf 1981). 


\section{RESULTS}

\section{Oceanic site}

Total (chl $a, c$, and fucoxanthin) light-harvesting pigment concentrations of Fucus vesiculosus varied ( $t$ test, $\mathrm{p}<0.0001$ ) between high and low intertidal populations at Ft. Wetherill, the oceanic site (Table 1). Low intertidal fronds had $70 \%$ higher levels of total pigments than the high intertidal population. In contrast, tissue $\mathrm{N}$ concentrations were not different between populations ( $t$-test, $\mathrm{p}>0.05$ ). Irradiance differences between regions therefore was the likely factor determining pigment variability, not differential nitrogen availability related to submergence time.

Similar to Fucus vesiculosus from the estuarine site (Yates \& Peckol 1993), phlorotannin levels varied greatly with time at the oceanic site (Fig. 1). Higher levels of phlorotannins were found in the high intertidal population (2-way ANOVA, site: $F=41.1, \mathrm{p}<$ 0.0001 ) than in low intertidal fronds, and peak concentrations occurred in both populations during the early summer period (Tukey's, $p<0.05$ ). Both populations showed depressed levels of phlorotannins during late winter, again mirroring findings for the estuarine population (Yates \& Peckol 1993).

During June, the period of peak phlorotannin levels of both oceanic populations (Fig. 1), we measured distinctive responses to experimental treatments by high and low intertidal Fucus vesiculosus (Fig. 2). While grazing resulted in no change in phenolics compared

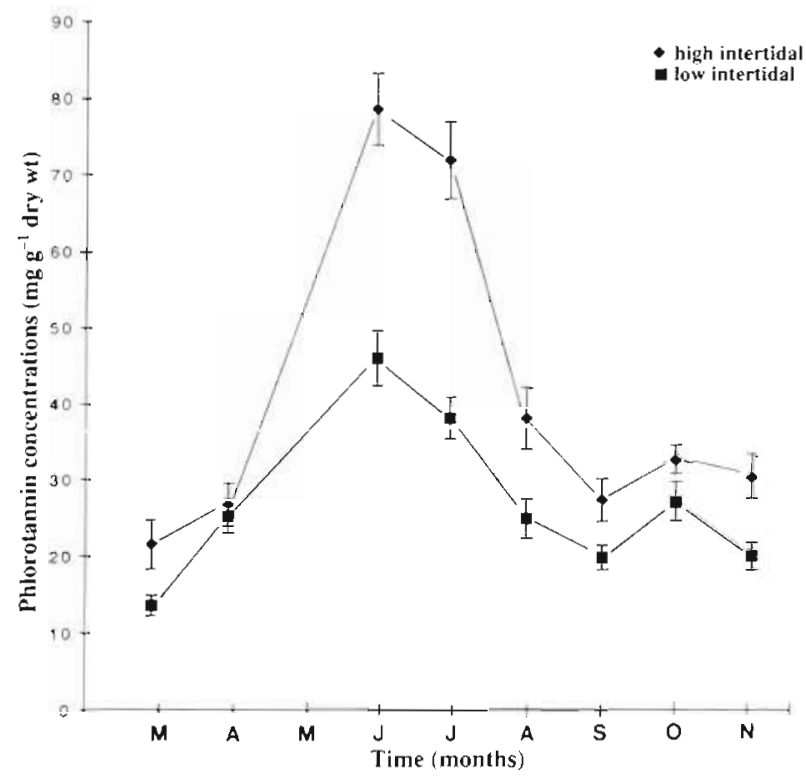

Fig. 1 Total (mean \pm SE) phlorotannin levels $\left(\mathrm{mg} \mathrm{g}^{-1}\right.$ dry wt) with time in high and low intertidal populations of Fucus vesiculosus at the oceanic site (Ft. Wetherill State Park, Jamestown, RI, USA)
Table 1 Mean ( \pm SE) concentrations ( $\mathrm{mg} \mathrm{g}^{-1}$ dry wt) of total ( $n=10$ ) light-harvesting pigments (chl $a, c$, and fucoxanthir) and tissue nitrogen $(n=3)$ for high and low intertidal populations of Fucus vesiculosus from Ft. Wetherill State Park, Jamestown, RI, USA

\begin{tabular}{lcc}
\hline Tidal height & Total pigments & Tissue nitrogen \\
\hline High intertidal & $6.0 \pm 0.7$ & $11.5 \pm 2.4$ \\
Low intertidal & $10.4 \pm 2.8$ & $12.8 \pm 2.3$ \\
\hline
\end{tabular}

with control fronds at Day 3 or 14 for the high intertidal population, grazed low intertidal $F$. vesiculosus had significantly higher $(t=5.0, \mathrm{p}<0.001)$ phlorotannins than control fronds by Day 3 , increasing this difference by Day 14 (ANOVA, $F=18.5, \mathrm{p}<0.00001$; Tukey's, $\mathrm{p}<$ $0.05)$. For the low intertidal population, the grazed + enriched treatment showed levels of phlorotannins intermediate (Tukey's, $p<0.05$ ) between grazed and control conditions by Day 14 (Fig. 2).

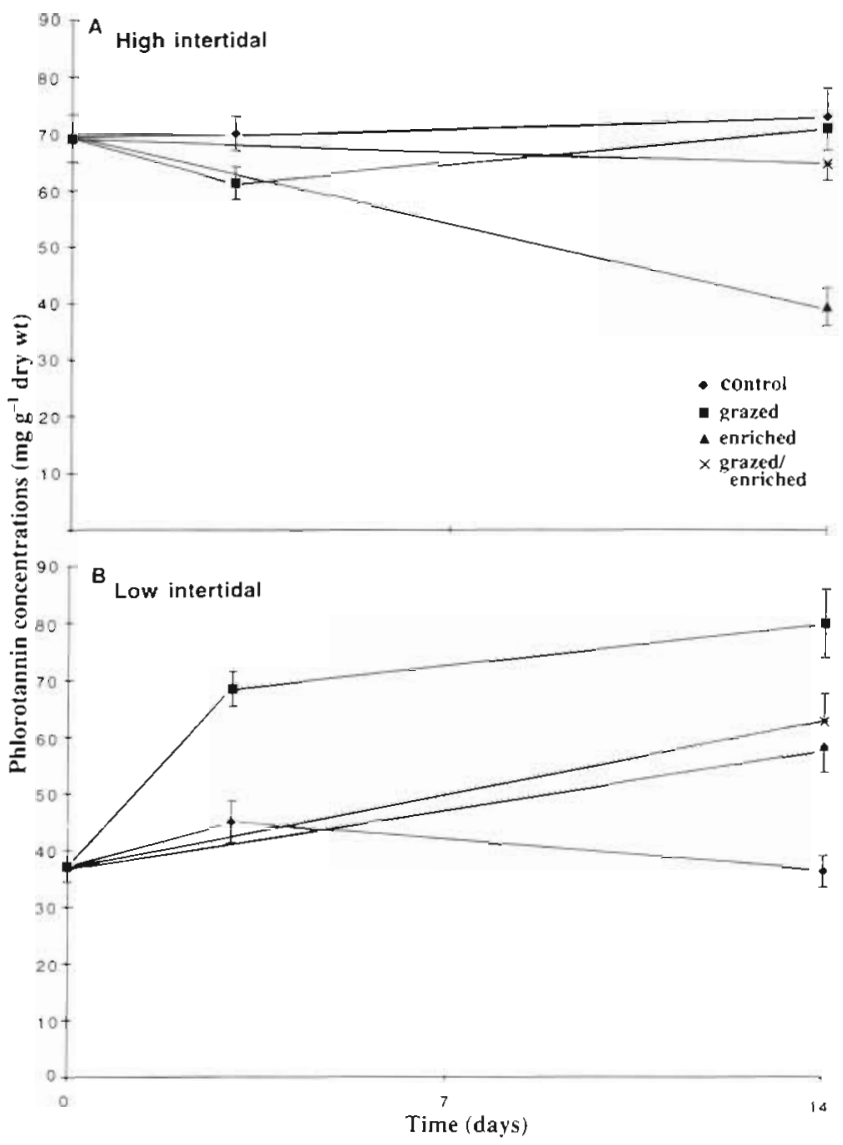

Fig. 2. Total (mean $\pm \mathrm{SE}$ ) phlorotannin levels ( $\mathrm{mg} \mathrm{g}^{-1}$ dry wt) during June (water temperature, $W T=14^{\circ} \mathrm{C}$ ) following various treatment conditions (see 'Materials and methods') in (A) high and (B) low intertidal populations of Fucus vesiculosus at the oceanic site 
Enrichment and grazing effects on phlorotannin levels of high and low intertidal populations of Fucus vesiculosus during August, a time of declining phlorotannins (Fig. 1), are shown in Fig. 3. Both oceanic populations showed increased production in response to simulated grazing by Day 7 (high intertidal: ANOVA, $F=5.0, \mathrm{p}<0.005$; low intertidal: ANOVA, $F=6.9, \mathrm{p}<$ 0.001 ) that was maintained for $2 \mathrm{wk}$. Although the grazed + enriched treatment resulted in elevated phlorotannins in the low intertidal population by Day 7 (Tukey's, $p<0.05$ ), levels in this treatment were elevated (Tukey's, $\mathrm{p}<0.05$ ) above control and enriched fronds in the high intertidal population only by Day 14. As found in June (Fig. 2), phlorotannins in the grazed + enriched treatment were intermediate (Tukey's, p < 0.05 ) between grazed and control (and enriched) fronds at $14 \mathrm{~d}$ for the low intertidal population.

Similar to the August experiment (Fig. 3), the oceanic populations of Fucus vesiculosus showed a marked response to grazing during October (Fig. 4). By Day 3, phlorotannin concentrations of grazed fronds of the high intertidal population were significantly

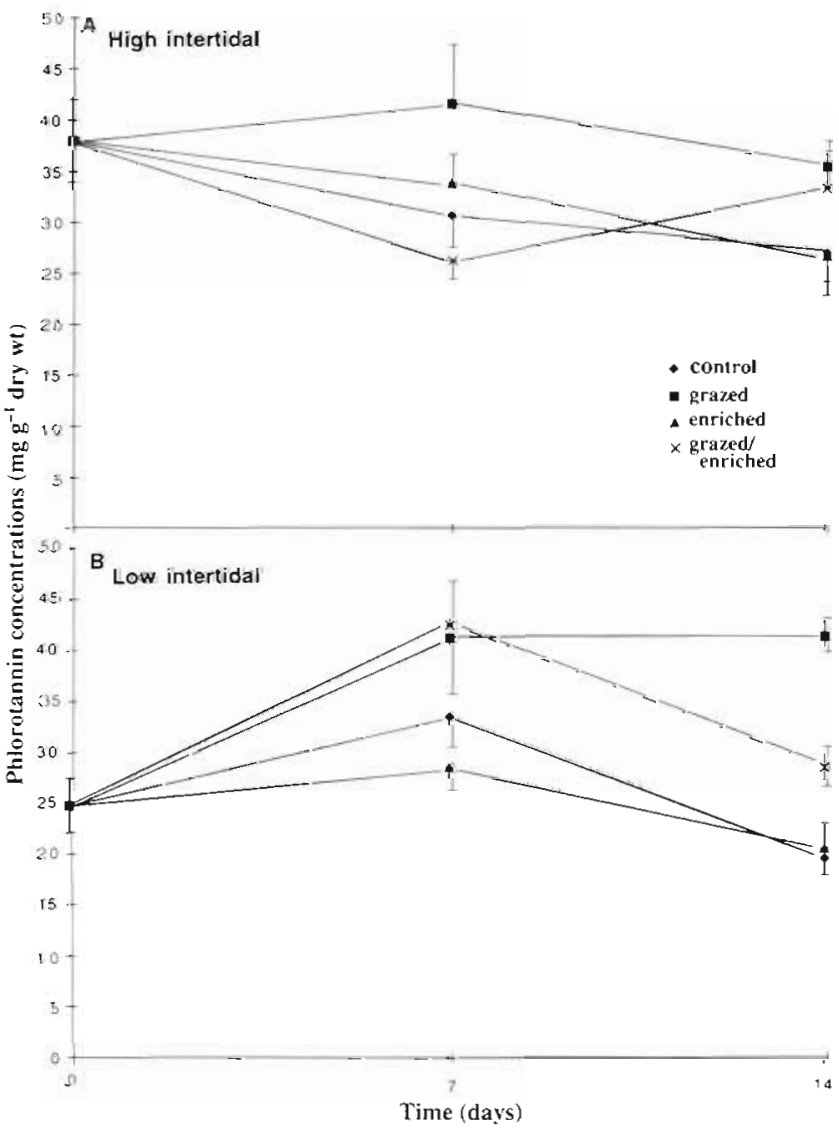

Fig. 3. Total (mean $\pm \mathrm{SE}$ ) phlorotannin levels ( $\mathrm{mg} \mathrm{g}^{-1}$ dry wt) during August ( $\mathrm{WT}=18^{\circ} \mathrm{C}$ ) following various treatment conditions in (A) high and (B) low intertidal populations of Fucus vesiculosus at the oceanic site

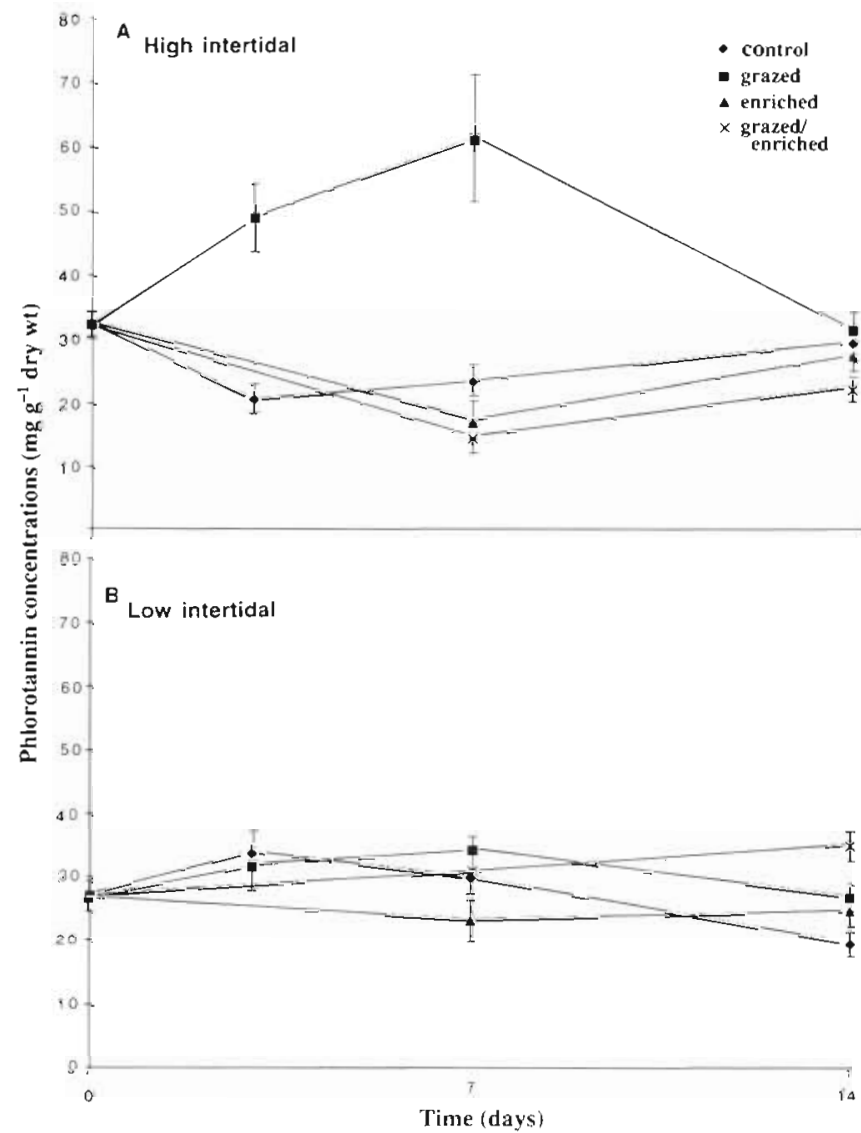

Fig. 4. Total (mean \pm SE) phlorotannin levels ( $\mathrm{mg} \mathrm{g}^{-1}$ dry wt) during October $\left(W T=15^{\circ} \mathrm{C}\right.$ ) following various treatment conditions in (A) high and (B) low intertidal populations of Fucus vesiculosus at the oceanic site

greater $(t$-test, $\mathrm{p}<0.05)$ than control fronds. This difference was maintained for $1 \mathrm{wk}$ (ANOVA, $F=19.8$, $\mathrm{p}<0.0001$ ), but by Day 14, levels were comparable (ANOVA, $\mathrm{p}>0.05$ ) to the other treatment conditions. The low intertidal population showed a slight response to grazing by Day 3; by Day 14, the grazed and grazed + enriched fronds had significantly (ANOVA, $F=11.5, \mathrm{p}<0.0001$ ) greater levels of phlorotannins than control fronds.

Although there was an elevation in phlorotannins in the grazed treatment compared with controls by Day 3 for both high and low intertidal populations during March (Fig. 5), this difference was not significant ( $t$ tests, $p>0.05)$. At the end of the $14 \mathrm{~d}$ experiment ( 3 April), there were no significant (ANOVA, $p>0.05$ ) treatment differences.

With the exception of a significant (Tukey's, p < 0.05) decline in phlorotannins associated with $\mathrm{N}$ enrichment in the June experiment for the high intertidal population (Fig. 2) and a brief depression (Day 7 only) for the low intertidal population during October (Fig. 4), there was no consistent effect of $\mathrm{N}$ enrichment on phlorotan- 
nin levels for the oceanic populations (Figs. 2-5). We did, however, measure a significant (ANOVA, $F=5.51$, $p<0.05)$ inverse relationship between tissue $N$ and phlorotannins (Fig. 6), as found by Yates \& Peckol (1993) for estuarine Fucus vesiculosus, and predicted by the $\mathrm{C} \mathbb{N}$ balance model. However, with an $\mathrm{R}^{2}$ of 0.20 , these 2 variables were not strongly coupled.

\section{Estuarine site}

At Sage Lot Pond, the response of Fucus vesiculosus to experimental treatments varied with season. During June, the period of peak concentrations (Yates \& Peckol 1993), phlorotannin levels did not vary (ANOVA, $p>0.05$ ) from control fronds when experimentally grazed or $\mathrm{N}$-enriched (Table 2). A clear response to experimental manipulation occurred when phlorotannin levels were declining in $F$. vesiculosus from late summer through autumn (Yates \& Peckol 1993). During both August and October, phlorotannins

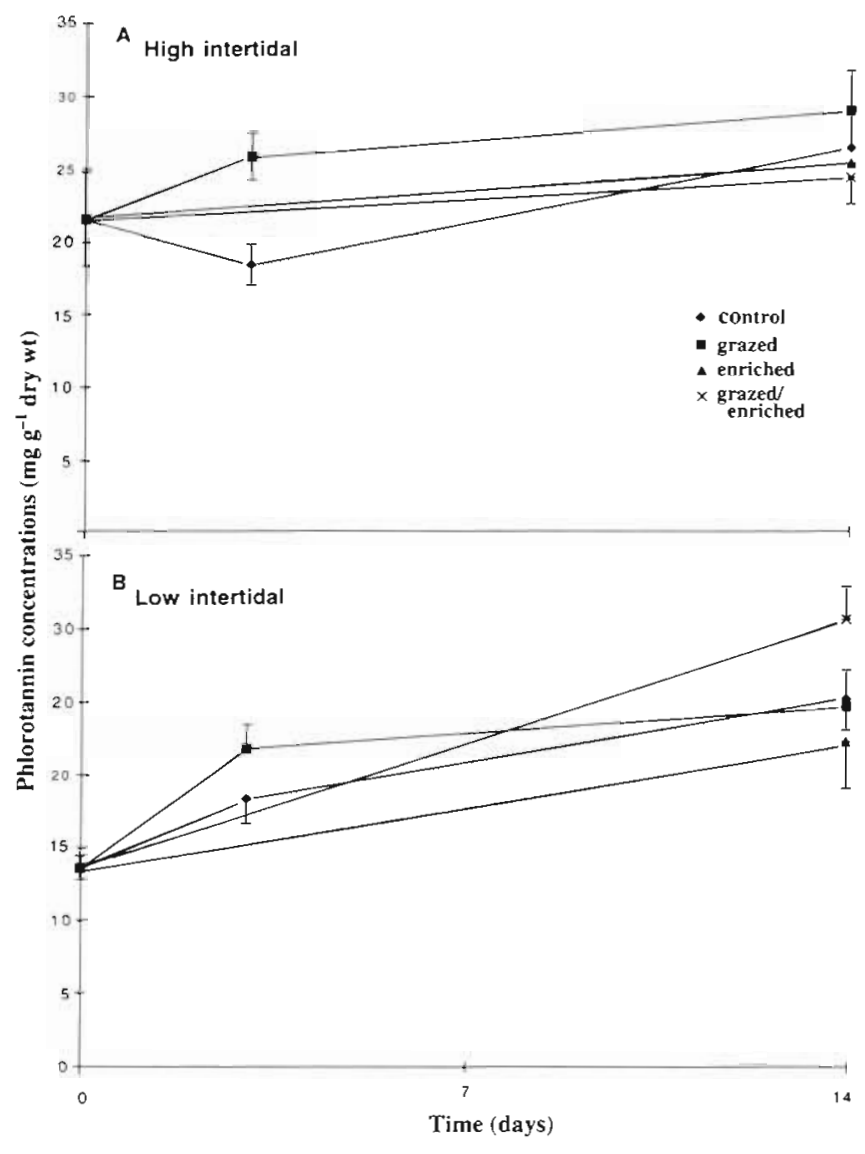

Fig. 5. Total (mean \pm SE) phlorotannin levels ( $\mathrm{mg} \mathrm{g}^{-1}$ dry wt) during March ( $\mathrm{WT}=4^{\circ} \mathrm{C}$ ) following various treatment conditions in (A) high and (B) low intertidal populations of Fucus vesiculosus at the oceanic site

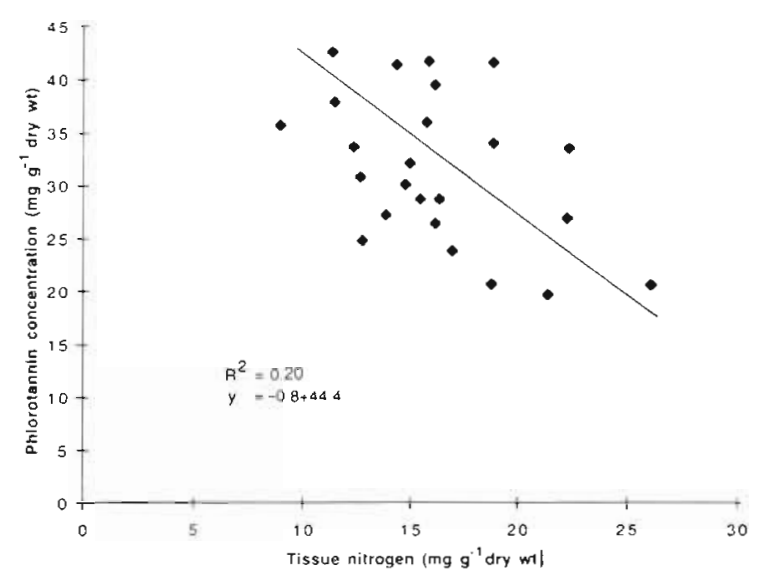

Fig. 6. Tissue $\mathrm{N}$ vs phlorotannin levels of Fucus vesiculosus from the oceanic site. Comparisons were drawn from means of experimental and control treatments after $2 \mathrm{wk}$ from August and October experiments

in the grazed and grazed + enriched treatments were higher (ANOVA, August: $F=7.2, \mathrm{p}<0.001$; October: $F=12.9, \mathrm{p}<0.00001)$ than in control and $\mathrm{N}$-enriched fronds. N-enriched fronds had lower levels (Tukey's, $\mathrm{p}<0.05$ ) than controls during both periods.

\section{DISCUSSION}

This study investigated the interactive effects of grazing and nutrient $(\mathrm{N})$ availability to establish the preeminence of either the induced defense or $\mathrm{C} / \mathrm{N}$ balance model as explanation of what triggers production of phlorotannins in the brown alga Fucus vesiculosus. Our results more strongly support the induced defense model; when we found a significant induced response, we generally measured elevated phlorotannin levels in both the grazed and grazed + enrichment treatments for both estuarine and oceanic populations of $F$, vesiculosus (Table 3 ). The response was relatively rapid, sometimes within $3 \mathrm{~d}$, and was generally of long (sensu

Table 2. Mean ( \pm SE) phlorotannin concentrations $\left(\mathrm{mg} \mathrm{g}^{-1} \mathrm{dry}\right.$ wt) of Fucus vesiculosus from Sage Lot Pond, Falmouth, MA, USA (estuarine site) under various treatment conditions during June, August and October, $14 \mathrm{~d}$ after initiating the experiments. Treatment conditions are described in text; $n=10$, each treatment

\begin{tabular}{|lcrr|}
\hline Treatment & June & August & October \\
\hline Control & $37.7 \pm 2.6$ & $30.5 \pm 3.8$ & $27.6 \pm 3.9$ \\
Grazed & $38.4 \pm 2.1$ & $40.2 \pm 2.1$ & $44.4 \pm 7.8$ \\
Enriched & $33.9 \pm 2.6$ & $19.4 \pm 2.8$ & $9.0 \pm 0.9$ \\
Grazed + enriched & $34.8 \pm 2.0$ & $39.8 \pm 4.6$ & $37.7 \pm 3.3$ \\
& & & \\
\hline
\end{tabular}


Karban \& Myers 1989) duration. For example, phlorotannins remained elevated for at least $2 \mathrm{wk}$ in $85 \%$ of the induced responses of the grazed treatment. During some periods, e.g. March, we found only a minimal induced response. While $N$ enrichment did result in depressed phenolic levels in estuarine $F$. vesiculosus, as predicted by the $\mathrm{C} / \mathrm{N}$ balance model, this treatment rarely resulted in a decline in phlorotannins at the oceanic site. Such site-related and temporal differences of this algal species in response to experimental conditions suggests that phlorotannin production is controlled by a complex interaction of environmental developmental (e.g. onset of reproductive stage) and defense-related factors, emphasizing the applicability of both models to marine systems.

Although Van Alstyne (1988) and Yates \& Peckol (1993) also documented an inducible defense in Fucus spp., the generality of this response in brown algae has not yet been established (Hay \& Fenical 1992). Renaud et al. (1990) documented a potential inducible response for the period of 1 to $5 \mathrm{~d}$ for the North Carolina (USA) brown alga Padina gymnospora (Dictyotales), and Peckol et al. (1992) measured an inducible defense in Caribbean brown algae Padina sanctae-crucis and Lobophora variegata (Dictyotales), but not Turbinaria turbinata (Fucales). North Atlantic Laminaria saccharina (Laminariales), a species with low $\left(<10 \mathrm{mg} \mathrm{g}^{-1}\right.$ dry wt) phlorotannin levels, did not show an inducible response in field experiments (Peckol unpubl. data). Steinberg (1994) found no evidence of elevated phlorotannins in Ecklonia radiata (Laminariales) or Sargassum vestitum (Fucales) under experimental conditions similar to ours, and suggested that these temperate Australasian brown algae, notable in maintaining high levels of phlorotannins (Steinberg 1989), show constitutive defenses. Perhaps the intensity of grazing pressure is greater (Estes \& Steinberg 1988) or the annual range in herbivore activity is less in the Australasian system than in New England (USA).

Table 3. Percentage of field experiments (oceanic site $=4$ experiments at each tidal height; estuarine site $=3$ experiments) showing significant $(p<0.05)$ changes in phlorotannins (relative to controls) of Fucus vesiculosus in response to the grazed, enriched or grazed + enriched treatments after 7 or $14 \mathrm{~d}$. Direction of change is indicated with $\uparrow$ (increased) or $\downarrow$ (decreased)

\begin{tabular}{|lrcc|}
\hline \multirow{2}{*}{ Treatment } & \multicolumn{2}{c|}{ Site } & \\
& Oceanic & Estuarine \\
\hline Grazed & $50 \% \uparrow$ & $75 \% \uparrow$ & $67 \% \uparrow$ \\
Enriched & $25 \% \downarrow$ & $25 \% \uparrow / 25 \% \downarrow$ & $67 \% \downarrow$ \\
Grazed/enriched & $25 \% \uparrow$ & $75 \% \uparrow$ & $67 \% \uparrow$ \\
\hline
\end{tabular}

Either situation would likely favor a constitutive defense in Australasian algae (Harvell 1990, Karban 1993, Steinberg 1994). However, further work is necessary to experimentally establish the basis of the temporal and spatial variation in the inducible response documented for Fucus spp. (Van Alstyne 1988, Yates \& Peckol 1993, this study), as well as to identify geographic trends in defensive mechanisms for brown algae

The lack of an inducible response during the periods of highest available irradiance and peak phlorotannin levels (June, except for the low intertidal oceanic population) and of low irradiance, temperature, and phenolic levels (March) may reflect temporal variation in resource allocation between primary and secondary metabolism, in accord with the $\mathrm{C} / \mathrm{N}$ balance model. Herms \& Mattson (1992) predicted that during periods of high growth, secondary metabolism may be substrate or energy-limited as growth processes receive allocation priority. Peak growth rates for Fucus vesiculosus during early summer (Carlson 1991, Peckol unpubl. data) may require all available photosynthate, leaving little for additional phlorotannin production for grazer resistance. Further, it was only during this period that $\mathrm{N}$ enrichment resulted in a depression of phlorotannins for the high intertidal population, again suggestive of a trade-off between growth and secondary metabolism under resource-rich conditions (Herms \& Mattson 1992). However, the strong induced response of the low intertidal population during this period is difficult to explain in this context. The minimal induced response during March may reflect higher ambient nutrient levels and consequent elevated tissue $\mathrm{N}$ in $F$. vesiculosus (Asare \& Harlin 1983, Yates \& Peckol 1993) or fixed-C limitation due to reduced irradiances and temperatures. Both conditions should negate an inducible response (Bryant et al. 1983, Karban \& Myers 1989, Herms \& Mattson 1992). Because of the nonlinear effects of resource availability on secondary metabolism (Herms \& Mattson 1992), it is difficult to predict the trade-off between growth and secondary metabolism.

The variation in phlorotannins with tidal height, i.e. consistently greater concentrations in high intertidal Fucus vesiculosus, is predicted by the $\mathrm{C} / \mathrm{N}$ balance model (Bryant et al. 1983, Fajer et al. 1992, Herms \& Mattson 1992). However, low intertidal Fucus had $70 \%$ greater levels of light-harvesting pigments than the high intertidal population, and both populations had similar C: $N$ ratios of $\sim 26$ (authors' unpubl. data). Ramus et al. (1977) documented higher photosynthetic rates (and greater light-harvesting pigments) of shade-acclimated, compared with sun-acclimated, F. vesiculosus at all experimental depths. Thus, the high and low intertidal populations in the present study may 
have similar in situ $\mathrm{C}$ fixation rates, making it unlikely that variation in phlorotannin concentration with tidal height is directly related to differences in resource availability.

The distinctive seasonality of phlorotannin levels found for the estuarine (Yates \& Peckol 1993) and oceanic (this study) populations of Fucus vesiculosus was correlated with annual variations of irradiance for this geographic location (Peckol \& Rivers 1996), again suggestive of a connection to $\mathrm{C} / \mathrm{N}$ balance because of large-scale differences in resource (light) availability (Bryant et al. 1983). While temporal patterns of phlorotannins of $F$. vesiculosus contrast sharply with a lack of seasonality for $F$. distichus (Van Alstyne 1988), Sargassum globulariaefolium (Steinberg 1986) and $S$. vestitum (Steinberg 1994), Steinberg \& van Altena (1992) documented considerable seasonality in phlorotannin levels of several Australian brown algae, but peak concentrations occurred during spring at this location. Further, Ragan \& Jensen (1978) found a winter peak of phlorotannin levels in Norwegian populations of $F$. vesiculosus and Ascophyllum nodosum. Rather than correlating with available irradiances, metabolites of these fucoid algae were inversely related to development of reproductive structures. Similarly, phlorotannin levels of estuarine (Yates \& Peckol 1993) and oceanic (this study) North American populations of $F$. vesiculosus decline through late summer-autumn corresponding with development of receptacles. Because light (quality and quantity) and reproductive periodicity are tightly coupled in algae (Lüning 1990), identifying causality among the variables will require careful experimental manipulation. However, the conflicting seasonal patterns of phlorotannins cited above, the large-scale pattern of higher phlorotannin concentrations in temperate versus tropical algae (Steinberg 1986, Van Alstyne \& Paul 1990, Steinberg et al. 1991, but see Targett et al. 1992), and an inability to induce elevated levels of polyphenolics under higher irradiances in the laboratory (Peckol \& Pardo unpubl. data) argue against a direct relationship between light availability and secondary metabolism.

Although environmental factors modify phlorotannin levels in Fucus vesiculosus as predicted by the $\mathrm{C} / \mathrm{N}$ balance model, the present study found greater support for the induced defense hypothesis. Karban \& Myers (1989) predicted that both $N$ and shading should negate an inducible response $e_{i}$ in the present study, low (shaded) and high intertidal populations showed similar inducible responses. Both estuarine and oceanic $F$. vesiculosus held under the 'grazed + enriched' treatment generally produced phlorotannin levels comparable to the 'grazed-only' treatment, further identifying the hierarchy of effects. As found by Yates \& Peckol (1993), only estuarine F. vesiculosus showed depressed levels of phenolics under $N$-enrichment. Perhaps higher grazing pressure at the oceanic site, where Littorina littorea occurs in densities $>100 \mathrm{~m}^{-2}$, acts to maintain phlorotannins at threshold level, i.e. a minimal induced resistance, in the oceanic populations. In fact, phlorotannin concentrations were consistently higher in oceanic populations than in estuarine fronds (compare Fig. 1 Yates \& Peckol 1993 with Fig. 1 this study). A similar lack of response to $\mathrm{N}$ enrichment in tropical brown algae (Peckol et al. 1992) where grazing intensity is notably high (see Gaines \& Lubchenco 1982 and references therein) suggests, as argued by Karban (1993), that if herbivory is relatively continuous, either seasonally or year-round, the alga may remain in an induced state.

Acknowledgements. We thank J Rivers, A. Classen, N. Pardo and S. Pitts for their help in the field and laboratory. The Waquoit Bay National Estuarine Research Reserve provided facilities support; Perkin-Elmer donated the elemental analyzer to the Marine Biological Laboratory. Sierra Chemical Co. generously donated the Osmocote fertilizer. Financial support was provided by an NSF-LMER grant (OCE 8914729) (to P.P.) and Smith College.

\section{LITERATURE CITED}

Andersen RA, Sowers JA (1968) Optimum conditions for bonding of plant phenols to insoluble polyvinylpyrrolidone. Phytochem 7:293-301

Andersen RA, Todd JR (1968) Estimation of total tobacco plant phenols by their bonding to polyvinylpyrrolidone. Tob Sci 12:107-111

Asare SO, Harlin MM (1983) Seasonal fluctuations in tissue nitrogen for five species of perennial macroalgae in Rhode Island Sound. J Phycol 19:254-257

Baldwin IT (1988a) Short-term damage-induced increases in tobacco alkaloids protect plant. Oecologia 75:367-370

Baldwin IT (1988b) The alkaloidal responses of wild tobacco to real and simulated herbivory. Oecologia 77:378-381

Baldwin IT, Schultz JC (1983) Rapid changes in tree leaf chemistry induced by damage: evidence for communication between plants. Science 221:277-279

Bryant JP. Chapin FS III, Klein DR (1983) Carbon/nutrient balance of boreal plants in relation to vertebrate herbivory. Oikos 40:357-368

Carlson L (1991) Seasonal variation in growth, reproduction and nitrogen content of Fucus vesiculosus $\mathrm{L}$. in the Oresund, southern Sweden. Botanica Mar 34:447-453

Carroll CR, Hoffman CA (1980) Chemical feeding deterrent mobilized in response to insect herbivory and counteradaptation by Eplacna tridecimnotata. Science 209: $414-416$

Day RW, Quinn GP (1989) Comparison of treatments after an analysis of variance in ecology. Ecol Monogr 59:433-463

Duncan MJ, Harrison PJ (1982) Comparison of solvents for extracting chlorophylls from marine macrophytes. Botanica Mar 25:445-447

Estes JA, Steinberg PD (1988) Predation, herbivory and kelp evolution. Paleobiology 14:19-36

Fajer ED, Bowers MD, Bazzaz FA (1992) The effects of nutrients and enriched $\mathrm{CO}_{2}$ environments on production of carbon-based allelochemicals in Plantago: a test of 
the carbon/mutrient balance hypothesis. Am Nat 140: $707-723$

Gaines SD, Lubchenco J (1982) A unified approach to marine plant-herbivore interactions. II. Biogeography. A Rev Ecol Syst 13:111-138

Gershenzon J (1984) Changes in the levels of plant secondary metabolites under water and nutrient stress. In: Timmermann BN, Steelink C, Loewus FA (eds) Photochemical adaptation to stress. Plenum Press, New York, p $273-320$

Harvell CD (1990) The ecology and evolution of inducible defenses. Q Rev Biol 65:323-340

Haukioja E, Neuvonen S (1985) Induced long-term resistance of birch foliage against defoliators: defensive or incidental? Ecology 66:1303-1308

Hay ME, Fenical W (1988) Marine plant-herbivore interactions: the ecology of chemical defense. A Rev Ecol Syst 19: 111-145

Hay ME, Fenical W (1992) Chemical meditation of seaweedherbivore interactions. In: John DM, Hawkins SJ, Price JH (eds) Plant-animal interactions in the marine benthos. Systematics association, spec vol 46. Clarendon, Oxford, $p$ 319-337

Hay ME, Steinberg PD (1992) The chemical ecology of plantherbivore interactions in marine vs terrestrial communities. In: Rosenthal GA, Berenbaum MR (eds) Herbivores: their interaction with plant secondary metabolites, Vol II: evolutionary and ecological processes. Academic Press, New York, p 371-413

Herms DA, Mattson WJ (1992) The dilemma of plants: to grow or defend. Q Rev Biol 67:283-335

Ilvessalo $\mathrm{H}$, Tuomi J (1989) Nutrient availability and accumulation of phenolic compounds in the brown alga Fucus vesiculosus. Mar Biol 101:115-119

Karban R (1993) Costs and benefits of induced resistance and plant density for a native shrub Gossypium thurberi. Ecology 74:9-19

Karban R, Myers JH (1989) Induced plant responses to herbivory. A Rev Ecol Syst 20:331-348

Levin DA (1971) Plant phenolics: an ecological perspective. Am Nat 105:157-181

Lobban CS, Harrison PJ, Duncan MJ (1985) Physiological ecology of seaweeds. Cambridge University Press, New York

Lüning K (1990) Seaweeds: their environment, biogeography, and ecophysiology. John Wiley \& Sons, Inc., New York

Mattson WJ (1980) Herbivory in relation to plant nitrogen content. A Rev Ecol Syst 11:119-161

Peckol P, DeMeo-Anderson B, Rivers J, Valiela I, Maldonado M. Yates J (1994) Growth, nutrient uptake capacities and tissue constituents of the macroalgae, Cladophora vagabunda and Graciaria tikvahiae, related to site-specific nutrient loading rates. Mar Biol 121:175-185

Peckol P, Levings S, Garrity S (1990) Kelp (Laminaria spp.) response following the World Prodigy oil spill in Narragansett Bay, Rhode Island. Mar Pollut Bull 21:473-476

Peckol P, Rivers JS (1996) Contribution by macroalgal mats to primary production of a shallow embayment under high and low nitrogen loading rates. Estuar Coast Shelf Sci 43: in press

Peckol P, Yates J, DeMeo-Anderson B (1992) Effects of nutrient availability and grazing on poylyphenolic concentrations in marine algae: a temperate and tropical comparison. Bull Ecol Soc Am 73:300

Ragan MA, Craigie JS (1978) Phenolic compounds in brown and red algae. In: Hellebust JA, Craigie JS (eds) Handbook of phycological methods: physiological and bio- chemical methods. Cambridge University Press, Cambridge, $p$ 157-179

Ragan MA, Glombitza KW (1986) Phlorotannins, brown algal polyphenols. In: Round FE, Chapman, DJ (eds) Progress in phycological research, Vol 4 . Biopress, Bristol, p $130-241$

Ragan MA, Jensen A (1978) Quantitative studies on brown algal phenols. II. Seasonal variation in polyphenol content of Ascophyllum nodosum (L.) Le Jol and Fucus vesiculosus (L.). J Exp Mar Biol Ecol 34:245-258

Ragan MA, Smidsrød O, Larsen B (1979) Chelation of divalent metal ions by brown algal polyphenols. Mar Chem 7: $265-271$

Ramus J, Lemons F, Zimmerman C (1977) Adaptation of lightharvesting pigments to downwelling light and the consequent photosynthetic performance of the eullttoral rockweeds Ascophyllum nodosum and Fucus vesiculosus. Mar Biol 42:293-303

Renaud PE, Hay ME, Schmitt TM (1990) Interactions of plant stress and herbivory: intraspecific variation in the susceptibility of a palatable versus unpalatable seaweed to sea urchin grazing. Oecologia 82:217-226

Seely R, Duncan MJ, Vidaver W (1972) Preparative and analytical extraction of pigments from brown algae with dimethylsulfoxide. Mar Biol 12:184-188

Sokal RR, Rohlf FJ (1981) Biometry. WH Freeman, New York

Steinberg PD (1986) Chemical defenses and the susceptibility of tropical marine brown algae to herbivores. Oecologia 69:628-630

Steinberg PD (1989) Biogeographical variation in brown algal polyphenolics and other secondary metabolites: comparison between temperate Australasia and North America. Oecologia 78:373-382

Steinberg PD (1994) Lack of short-term induction of phlorotannins in the Australasian brown algae Ecklonia radiata and Sargassum vestitum. Mar Ecol Prog Ser 112:129-133

Steinberg PD, Edyvane K, de Nys R, Birdsey R, van Altena IA (1991) Lack of avoidance of phenolic-rich brown algae by tropical herbivorous fishes. Mar Biol 109:335-343

Steinberg PD, Paul VJ (1990) Fish feeding and chemical defenses of tropical brown algae in Western Australia. Mar Ecol Prog Ser 58:253-259

Steinberg PD, van Altena IA (1992) Tolerance of marine invertebrate herbivores to brown algal phlorotannins in temperate Australasia. Ecol Monogr 62:189-222

Swain T (1979) Secondary compounds as protective agents. A Rev Plant Physiol 28:479-501

Swain T, Hillis WE (1959) The phenolic constituents of Prunus domestica. I. The quantitative analysis of phenolic constituents. J Sci Food Agric 10:63-68

Targett NM, Coen LD, Boettcher AA, Tanner CE (1992) Biogeographic comparisons of marine algal polyphenolics: evidence against a latitudinal trend. Oecologia 89: $464-470$

Van Alstyne KL (1988) Herbivore grazing increases polyphenolic defenses in the intertidal brown alga Fucus distichus. Ecology 69:655-663

Van Alstyne KL (1995) Comparison of three methods for quantifying brown algal polyphenolic compounds. J Chem Ecol 21:45-58

Van Alstyne KL, Paul VJ (1990) The biogeography of polyphenolic compounds in marine macroalgae: temperate brown alqal defenses deter feeding by tropical herhivnrous fishes. Mar Biol 109:335-343

Yates JL, Peckol P (1993) Effects of nutrient availability and herbivory on polyphenolics in the seaweed Fucus vesiculosus. Ecology 74:1757-1766 